\title{
IMPROVING ORGANIZATIONAL CITIZENSHIP BEHAVIOR (OCB) THROUGH STRENGTHENING ORGANIZATIONAL CLIMATE AND PERSONALITY
}

\author{
Nancy Yusnita, Widodo Sunaryo, and Sri Yulianti \\ Dept. of Management Science, Graduate School Pakuan University, Bogor, Indonesia \\ corresponding author: nancyyusnita@unpak.ac.id
}

\begin{abstract}
Many kinds of research on Organizational Citizenship Behavior (OCB) had generated findings that OCB is considered one of the main ways to increase organizations' effectiveness. This study examines factors that have a relationship with OCB, namely, organizational climate and personality. This study was conducted among Primary School teachers at Cileungsi District, Bogor, Indonesia. The sample for the study consisted of 152 permanent teachers derived randomly from its population which is 245 Primary School teachers. The study mainly utilized quantitative data (from questionnaires). Regression and correlational analysis were applied, with that the relationship among variables found. The findings revealed that the school organizational climate had a positive and significant relationship with OCB. Similarly, teachers' personalities had a positive and significant relationship with OCB. Both school organizational climate and teachers' personalities simultaneously had a strong positive and significant relationship with OCB. Further analysis was conducted to find out which indicators of those variables that had a dominant influence on OCB. Based on the indicator analysis results, this study proposed some recommendations toward Primary School Principals at Cileungsi District, Bogor to strengthen indicators of Organizational Climate and Personality that have a high coefficient of correlation with OCB. By strengthening those indicators it can be predicted will improve teachers' OCB.
\end{abstract}

Key words: Organizational Climate; Personality; Organizational Citizenship Behavior (OCB); Primary school teacher

\section{PENINGKATAN ORGANIZATIONAL CITIZENSHIP BEHAVIOR (OCB) MELALUI PENGUATAN IKLIM ORGANISASI DAN KEPRIBADIAN}

\begin{abstract}
ABSTRAK. Berbagai penelitian Organizational Citizenship Behavior (OCB) telah menghasilkan temuan bahwa OCB dianggap sebagai salah satu cara utama untuk meningkatkan efektivitas organisasi. Penelitian ini bertujuan untuk menemukan faktor-faktor yang memiliki hubungan dengan OCB yaitu iklim organisasi dan kepribadian. Penelitian ini dilakukan pada guru Sekolah Dasar di Kabupaten Cileungsi, Bogor, Indonesia. Sampel penelitian terdiri dari 152 guru tetap yang diambil secara acak dari populasinya. Studi ini terutama menggunakan data kuantitatif (dari kuesioner). Hasil pengolahan data melalui analisis regresi dan korelasional digunakan untuk mengetahui hubungan antar variabel. Hasil penelitian mengungkapkan bahwa iklim organisasi memiliki hubungan positif dan signifikan dengan OCB. Begitu pula dengan kepribadian, memiliki hubungan positif dan signifikan dengan OCB. Baik iklim organisasi sekolah dan kepribadian guru secara bersamaan memiliki hubungan positif dan signifikan yang kuat dengan OCB. Analisis lebih lanjut dilakukan untuk mengetahui indikator mana dari variabel-variabel tersebut yang berpengaruh dominan terhadap OCB. Berdasarkan analisis indikator reluts, penelitian ini mengajukan beberapa rekomendasi kepada Kepala Sekolah Dasar di Kabupaten Cileungsi untuk memperkuat indikator Iklim Organisasi dan Kepribadian yang memiliki koefisien korelasi tinggi dengan OCB. Dengan penguatan indikator tersebut diharapkan dapat meningkatkan OCB guru.
\end{abstract}

Kata kunci: Iklim Organisasi; Kepribadian; Organizational Citizenship Behavior (OCB); Guru Sekolah Dasar.

\section{INTRODUCTION}

In recent decade, the concept of OCB had changed the organizations' perspective that increasing organizational effectiveness require not just to drive individuals task performance but also should be combined it with increasing their OCB. Organizational effectiveness require individual who have highly performance as well as they have willingness to help each other while working together, to work more than just describe on their job description, and to share the responsibility for building company image, while their behavior have not been implied by the formal organizations reward system. Those individual behavior known as OCB. It is generally understood that $\mathrm{OCB}$ is when employees develop roles beyond their duties, such as serving by giving positive support for their organization, the behavior they exhibit is the level of stakeholders and organizational satisfaction and performance will increase (Messersmith et al., 2011). The concept of OCB, which is derived from Katz and Kahn (1966), while the concept of employee extra role behavior by Organ and his colleagues (Bateman \& Organ, 1983; Smith, Organ $\&$ Near, 1983) was to be the first appeared in the literature in studies. Then, the reconceptualizing OCB refines as any action of contributing work behavior that supports the social or psychological environment (Organ, 1997) which embedded in job tasks. The competitive advantage that employee OCBs can create at a high level in an organization 
can be understood in the idea of "The ability of an organization to get employee behavior that goes beyond assignment is a major advantage that is hard for other competitors to imitate (Bolino, 2003). OCB can be expressed as the sum of the Organization's informal behavior. Every managers may be immediately attracted to accepting OCB within their own Organization because of the beneficial effect this kind of behavior has on the performance of the Organization (Popescu, 2014). There are so many factors that impact the success of a school, such as an organization factor and even also an individual factor.

Fundamentally, success of schools depends on teachers who has willingness to go beyond role expectations voluntary (DiPaola et al., 2001). Many schools had improved methods of teaching, increased teachers' competencies and added more ICT elements in the curriculum in order to improve the effectiveness of educational process. But those improvement program had not achieved a certain level of optimal results. Most of teachers still had a lack of teamwork, less carefulness doing their tasks, and needed the tight supervision to finish their tasks. Considering of that we realized an urgency to find effective efforts in order to improve the educational process. This study start with conducting a preliminary survey toward primary school teachers at Cileungsi to investigate their working behavior. The survey found that $48 \%$ of teachers had lack of willingness to help each other, $43 \%$ of employees had lack of courtesy in doing their owned tasks, $47 \%$ of teachers had lack of conscientiousness in improving their planning in teaching process, $40 \%$ of teachers were unable to submit classroom learning report on scheduled, $46 \%$ of teachers had lack of effort to find ideas in solving classroom problem, and $43 \%$ of teachers had lack of willingnesss to conduct additional tasks beyond their main tasks (pre survey data). Those findings indicated that there were problem of teachers' OCB.

The survey (primary data were taken before field research) also identified that the organizational climate and job satisfaction assumed had influenced teachers' OCB. Organizational Climate can create a conducive school condition that drive teachers to conduct more effective work behavior. The positive teachers' Personality will strengthen teachers' behavior in the learning process. Regarding of that assumption, we formulated the study's objective is to analyze the relationship between school organizational climate and teachers' personality with teachers' OCB.

Colquitt, Lepine \& Wesson (2015) state that organizational citizenship behavior as voluntary employee activities that contribute to the organization by improving the overall quality of the setting in which work takes place without reward expected. Summarized from Colquitt, Lepine and Wesson, the Citizenship Behavior can be devided into two categories there are Interpersonal Citizenship Behavior and Organizational Citizenship Behavior. The first category is Interpersonal Citizenship Behavior. For example, Altruism involves helping coworkers who with heavy workloads, helping those with personal problems, and helping new employees when they first arrive at work. Manners refer to giving direction to co-workers about matters that are relevant to the job. Sportsmanship involves maintaining good relationships with coworkers, even when they have made work mistakes or when the unit is going through a difficult time. Carefulness refers to employees' willingness to work more concentration and careful toward their tasks. The second category of citizenship behavior is Organizational Citizenship Behavior (OCB). For example, Voice involves actively providing constructive suggestions for change. Citizenship refers to the contribution to a company's operations at a deeper level than usual by engaging in voluntary meetings and functions, understanding and following organizational rules, and actively seeking business news affecting the company. Boosterism means acting as an organizational agent by showing positive behavior when in public, away from the office, and away from work. (Langton, Robbins \& Judge, 2016; Turnipseed, 2005).

OCB is important for the organization because it supports the achievement of organizational goals and has implications for improving individual and organizational performance (Fisher, McPhail \& Menghetti, 2010). A The level of citizenship of a person's organization can be seen from the extent of his / her behavior makes a contributions that have a positive influence on the organization. For example, an employee who shows good work results in terms of quality and quantity. However, he refuses to work overtime, is unwilling to provide direction and guidance for new employees to adapt to his job, and is unwilling to contribute anything outside of his basic duties. This employee is seen as a person who is performing well, but he/she is not classified as a person who has a good OCB (Griffin \& Moorhead, 2014). The behavior of helps can stimulate better performance because new colleagues easily blend into the group. Therefore, the group can determine the best ways of working, facilitate coordination, and make decisions that will result in reduced 
differences in perceptions and ways of working. high level of compactness, it is easier to maintain the sustainability of the group (Zeinabadi, 2010). Organizational Citizenship Behavior is behavior that is expected for the continuity and achievement of organizational goals. Examples of OCB include helping colleagues without being asked; protect the organization from physical and reputational damage; provide constructive advice; develop personal skills and abilities; and show positive behavior in society. Sportsmanship can increase the passion of group members to be more high performing (George \& Jones, 2012). To increase the motivation of subordinates to perform better, the leadership can do this by empowering their subordinates (Oguz, 2010). By having a sense of wanting to do more, employees are not only doing their main job but are also more likely to show OCB outside of their job roles. (Chiang \& Hsiesh, 2012). Can be defined, teacher OCB is in all voluntary behavior and positive contributions made to the academic community and society (DiPaola, Tarter \& Hoy, 2004). The high OCB of employees can maximize efficiency and improve effectiveness in achieving organizational goals (Moorman et al, 1993). Many researchers have experimented with these factors causing the behavior, namely the Job factor Satisfaction, organizational commitment, organizational identity, and organizational justice. In addition, there are several other factors including trust, working in a team, protecting organizational behavior, voluntarily giving constructive ideas, self-training, maintaining the reputation of the organization and so on (Appelbaum et al., 2004; Oyesiku, et al. 1999; Podsakoff et al., 1997)

In its history, since the 1930s scholars have begun to study organizational climate (Ehrhart \& Kuenzi, 2015). Organizational climate as the perception of organizational members on the situation and conditions of the organization in which they work (Jorde-Bloom, 1988). Organizational climate refers to the factors that exist within an organization to achieve a performance, this is what differentiates it from the concept of organizational culture, although it has a different meaning. This implies that organizational members attribute their experiences at work, while culture represents the underlying assumptions and values that drive real experiences. This means that climate is the current manifestation of the values of organizational culture that are deeper and more abstract and can be shown in the form of interpersonal relationships and meanings that produce tangible work results. With this, organizational climate includes social attributes, which can be observed or understood, which makes organizational members feel desired to interact and show job performance in the organization (Asif, 1996; 2011; Fainshmidt, 2017)

In general, term "climate" refer to a way of showing the psychological relationship of a social situation. The social context for work has a marked effect on how a person's social relationships with coworkers at work, and their performance (Schneider \& Barbera, 2014). Organizational climate is the shared perception of the members of the organization in which they work in terms of policies, rules, and ways of managing the organization. The dimensions of organizational climate consist of employee relationship with his/her superior, interpersonal communication among employees, em[ployee's perception toward organization's policies, and the fairness feeling of employees toward management practices (Uhl-Bien, Schermerhorn, Jr. \& Osborn, 2014). Organizational climate as an organization's share perceptions of the organization where they work and shown on their attitude of work and the way they solve the problem in organization (Adenike, 2011). A finding research stated a conclusion that there was a strong relationship $(\mathrm{r}=0.68, \mathrm{p}<0.01)$ between Organizational Climate with organizational citizenship behavior. Khaeruddin (2020) described his research finding that there was a positive and significant relationship $(r=0.642 \mathrm{p}<0.05)$ between Organizational Climate with OCB (Gheisari, Sheikhy and Salajeghe, 2014).

Although no single definition is acceptable about the term of personality but most concepts of personality refer that personality as a form of relatively permanent traits and set of special characteristics that influence and described in a person's behavior (Feist, Feist \& Roberts, 2018). Personality traits are considered somewhat stable throughout someone's life, yet able to change if someone's motivated to do so over a long period of time (Peltonena et al., 2020). The study from McCrae and Costa (in Fesis, Fesist \& Roberts, 2018) found that there are five traits that become permanent characteristics of individual. First, Neuroticism trait defined as characteristics of individual who have high level of anxiety, temperamental, self-pitying, self-conscious, emotional instability, and vulnerable to stress-related disorders. Second, Extraversion trait defined as the characteristics of individual who have high level traits of affectionate, jovial, talkative, joiners, and fun-loving. Third, Openness to Experience trait defined as the characteristics of indvidual who have a high need for closure and who gain comfort in their association with familiar people and things. Fourth, 
Agreeableness trait defined as the characteristics of individual who tend to be trusting, generous, yielding, acceptant, and good-natured. Fifth, Conscientiousness trait defined as the characteristics of individual who are ordered, controlled, organized, ambitious, achievement focused, and self-disciplined. (Burger, 2019) explained the Five Personality characteristics in similar meaning. The Neuroticism dimension places people along a continuum according to their emotional stability and personal adjustment. People who frequently experience emotional distress and wide swings in emotions will score high on measures of Neuroticism. The second personality dimension, Extraversion, places extreme extraverts at one end and extreme introverts at the other. Extraverts are very sociable people who also tend to be energetic, optimistic, friendly, and assertive. The Openness dimension refers to openness to experience rather than openness in an interpersonal sense. The I characteristics that make up this dimension include an active imagination, a willingness to consider new ideas, divergent thinking, and intellectual curiosity. People who are high on the Agreeableness dimension are helpful, trusting, and sympathetic. Agreeable people prefer cooperation over competition. The Conscientiousness dimension refers to how controlled and self-disciplined we are. People on the high end of this dimension are organized, plan oriented, and determined (Burger, 2019). Despite the popularity of the Big Five personality model, there are several criticisms of it: personalities can change; "Big" is meant to describe the breadth of these qualities rather than the greatness of their perfection; and the model is not intended to be a comprehensive presentation of personality (O.P. John et al., 1999)

A research finding by Mushraf et. al (2015), stated that there was a positive and significant relationship $(r=0.690 \mathrm{p}<0.01)$ between Personality with OCB (). Again, a research by Sukanti et al (2017) shows that there was a positive and significant relationship $(r=0,568 p<0.05)$ between Personality with OCB. Based on a review of the literature on the factors affect organizational citizenship behavior, it was found that the big-five personality traits: extraverted personality, agreeable personality, conscientious personality, emotionally stable personality, and open to experience personality have effects on organizational citizenship behavior (Mahdiuon, Ghahramani, \& Sharif, 2010; Singh \& Singh, 2009).

As on the theoretical description and research finding above mentioned, this study generated 3 hypotheses. First, there is a positive relationship between organizational climate with organizational citizenship behavior. Second, there is a positive relationship between personality with organizational citizenship behavior. Third, there is a positive relationship between organizational climate and personality simultaneously with organizational citizenship behavior. This study aim is to find the relationship between variables and to determine factors that have a significant contribution to increasing organizational citizenship behavior.

\section{METHODS}

This study apply correlational quantitative methods, which is research conducted by researchers to determine the level of the relationship between two or more variables, without making changes, additions or manipulations to existing data (Arikunto, 2013). The study conducted at Primary School in Cileungsi District, Bogor, during April up to December 2019. This study was conducted in Cileungsi District Bogor because we found indicate the existence of OCB problems in the area (pre survey data). This Study mainly utilized quantitative data (from questionnaires). By using simple random sampling, the amount of 152 sample calculated by Slovin formula at $\mathrm{p}<0.05$ and randomly took from 245 Primary School teachers as the population. The questionnaires designed to assessed indicators of OCB, Organizational Climate and Personality using point of 1 to 5 Likert Scale.

The questionnaire has been tested of 30 sample from its population but out of research sample in order to measure each validity and reliability as reported in the table 1.

Table 1. The Valid Items and Reliability of the Questionnaires

\begin{tabular}{llcc}
\hline No & \multicolumn{1}{c}{ Questionnaire of } & $\begin{array}{c}\text { Sum of } \\
\text { Valid Items }\end{array}$ & $\begin{array}{c}\text { Reliability } \\
\text { Coefficient }\end{array}$ \\
\hline 1 & $\begin{array}{l}\text { Organizational Citizenship } \\
\text { Behavior (OCB) }\end{array}$ & 33 & 0.903 \\
2 & Organizational Climate & 33 & 0,905 \\
3 & Personality & 32 & 0.906 \\
\hline
\end{tabular}

Source: processed primary data (2019)

Notes:

1. Each questionnaire initially had 40 items and already tested out (used 30 sample). Some items were dropped-out, and the remain is the valid items only. The item validity coefficient calculated by Pearson's Product-Moment Correlation formula (Nolan \& Heinzen, 2012).

2. The questionnaires reliability coefficient calculated by Cronbach Alpha's formula (Sekaran \& Bougie, 2013). 
The research design is a correlational study which described as the figure 1 .

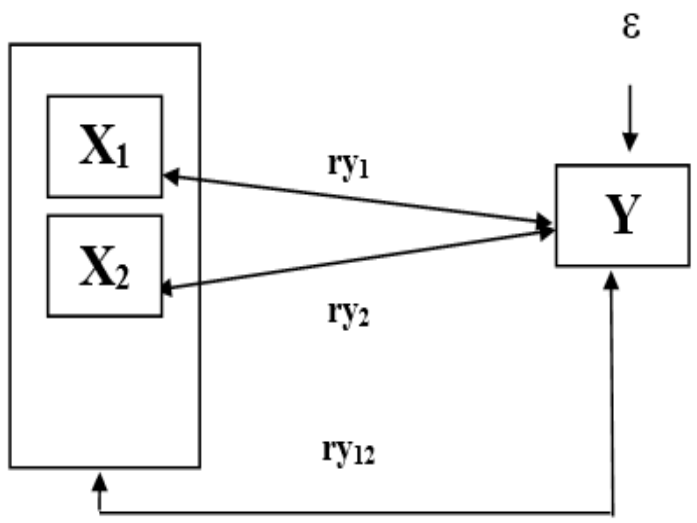

Figure 1. The Relationship between Research Variables

Description:

Y : Organizational Citizenship Behavior

$\mathrm{X} 1$ : Organizational Climate

$\mathrm{X} 2$ : Personality

ry1 : Coefficient of Correlation between X1 with Y

ry2 : Coefficient of Correlation between $\mathrm{X} 2$ with $\mathrm{Y}$

ry12: Coefficient of Correlation between $\mathrm{X} 1$ and $\mathrm{X} 2$ simultaneously with $\mathrm{Y}$

$\varepsilon \quad:$ Epsilon (the unknown variable).

Based on all questionnaires' scores from 152 teachers as the research sample to be analyzed stage by stage. First, testing the normality of empirical data from research sample used Lillifors Formula. This procedure used to examine that research sample coming from a population with normal distribution. Second, testing the linearity of empirical data from research sample applied Regression Analysis. To examine that the relationship of the data from OCB, Organizational Climate and Personality meet the criteria of linearity we use the procedure of linearity test. To meet the requirement for using parametric statistics, the normality and linearity results were required. Third, conducted correlational analysis to measure the strength of relationship between Organizational Climate and Personality partially and simultaneously with OCB. Fourth, conducted the Indicators Analysis in order to find out which indicators of Organizational Climate and Personality that had strong relationship with indicators of OCB.

\section{RESULTS AND DISCUSSION}

The normality test of empirical data from research sample used Lillifors Formula. This procedure used to examine that research sample coming from a population with normal distribution.

Normality Test for Empirical Data from Research Sample can be described in table 3 .

Based on Normality Test results above show which empirical data is lower than Lillifors
Standard, it can be recognized that scores from each questionnaires of employess' OCB to Organizational Climate and Personality coming from a population with a normal distribution. It means that this result meet one of the requirement for analyzing sample data to generate conclusion of the population.

Table 2. Normality Test Results

\begin{tabular}{|c|c|c|c|}
\hline No & Description & $\begin{array}{c}\text { OCB to } \\
\text { Organizational } \\
\text { Climate }\end{array}$ & $\begin{array}{c}\text { OCB to } \\
\text { Personality }\end{array}$ \\
\hline 1 & Empirical Data & 0.066 & 0.072 \\
\hline 2 & $\begin{array}{l}\text { Lillifors' } \\
\text { Standard* }\end{array}$ & 0.065 & 0.072 \\
\hline 3 & Results & $\begin{array}{l}\text { Empirical }< \\
\text { Standar }\end{array}$ & $\begin{array}{l}\text { Empirical }< \\
\text { Standar }\end{array}$ \\
\hline
\end{tabular}

* Supardi US (2012: Lilliefors Table)

Linearity Test of empirical data from research sample used Regression Analysis. This procedure used to examine that the relationship between Organizational Climate with $\mathrm{OCB}$, and between Personality with OCB should meet the standard linear regression, as described 3 :

Table 3. Linearity Test Results

\begin{tabular}{|c|c|c|c|}
\hline No & Descriptions & $\begin{array}{l}\text { Relationship } \\
\text { between } \\
\text { Organizational } \\
\text { Climate with } \\
\text { OCB } \\
\end{array}$ & $\begin{array}{l}\text { Relationship } \\
\text { between } \\
\text { Personality with } \\
\text { OCB }\end{array}$ \\
\hline 1 & $\begin{array}{l}\text { Deviation from } \\
\text { Linearity (empirical) }\end{array}$ & 0.340 & 0.580 \\
\hline 2 & $\begin{array}{l}\text { Standard of } \\
\text { Significance }(\mathrm{p}<0.05)^{*}\end{array}$ & 1.770 & 1.760 \\
\hline 3 & Results & $\begin{array}{c}\text { Empirical < } \\
\text { Standard }\end{array}$ & $\begin{array}{c}\text { Empirical < } \\
\text { Standard }\end{array}$ \\
\hline
\end{tabular}

Based on Linearity Test Results above showed where empirical deviation from linearity is lower than the standard of significance level $(\mathrm{p}<0.05)$, it can be concluded that the relationship between organizational climate with OCB and between job satisfaction with OCB had met the regression linearity criteria. It means that this results had met one of the requirement for analyzing sample data to generate conclusion of the population.

CorrelationalAnalysisResults. The correlational analysis technique used to test the hypotheses. This analysis used Product-Moment Correlation Formula and applied t-test procedure with 0.05 minimum level of significance, as described in the table 4 .

Based on Correlational Analysis Results above showed, it can be concluded that all research hypotheses were accepted. The present correlation coefficient of organizational climate with OCB ( $\mathrm{r}$ $=0.380$ ) had a similar positive direction compared with prior related research had found that correlation 
coefficient and standardized path coefficient between organizational citizenshipbehaviorand organizational climate are 0.35 and $0.68(\mathrm{p}<0.05)$ respectively. It means in the office where the organizational climate is in good standing the organizational citizenship behavior of employees will occur more (Pourkiani, Farokhian and Gheisarithe, 2014). The present correlation coefficient of Personality with OCB $(r=0.413)$ had similar positive direction with prior related research that had conducted which investigated the effect of personality factor on organizational citizenship behavior (Kholisah, Sampeadi, and Apriono, 2020). The results of this research show that the personality has a significant effect on OCB $(b=0.250 \mathrm{p}<0.05)$. This indicates that employee personality is as expected that will lead to the formation of a good OCB. The present multiple correlation coefficient between organizational climate and personality simultaneously with OCB ( $\mathrm{r}$ $=0.681$ ) can be interpreted that organizational climate and personality had a synergized effect toward OCB.

The final statistical analysis was to find out which indicators of Organizational Climate and Personality that had strong relationship with indicators of $\mathrm{OCB}$ as described in the table 5.
Based on Indicator Analysis Results above showed, it can be identified that indicator Leadership Style and Management Policies from Organizational Climate variable and indicator Extraversion, Openness to Experience, and Conscientiousness from Personality variable had strong relationship at least with two indicators of OCB. So it can be predicted that any effort to strengthen those indicators will improve teachers' OCB.

\section{CONCLUSIONS}

The scope of this study had limitations. Population and sample of teachers utilized in this study just Primary School teachers at Cileungsi District. So the results of this study can be generalized to its population only. This study just investigated two variables (Organizational Climate and Personality) that had relationship with OCB. Theoretically, it can be identified that many variables might have influenced OCB. We recommend for the next other studies to utrilize a large population and sample and also investigate more variables that might influence the OCB.

Table 4: Correlational Analysis Results

\begin{tabular}{clccc}
\hline No & Description & $\begin{array}{c}\text { The Correlation between } \\
\text { Organizational Climate with OCB }\end{array}$ & $\begin{array}{c}\text { The Correlation } \\
\text { between Personality } \\
\text { with OCB }\end{array}$ & $\begin{array}{c}\text { The Multiple Correlation } \\
\text { between Organizational Climate } \\
\text { and Personality with OCB }\end{array}$ \\
\hline 1 & $\begin{array}{l}\text { Coefficient } \\
\text { Correlation (r) }\end{array}$ & 0.380 & 0.413 & 0.681 \\
2 & $\begin{array}{l}\text { Empirical } \boldsymbol{t} \text { Score } \\
\text { Standard } \boldsymbol{t} \text { Score } \\
(\mathrm{p}<0.05)^{*}\end{array}$ & 21.586 & 24.658 \\
4 & Results & 1.980 & 1.980 & 3.070 \\
Empirical $>$ Standard & Empirical $>$ Standard & Empirical $>$ Standard
\end{tabular}

* Supardi US (2012: t-Table)

Table 5. Indicators Analysis Results

\begin{tabular}{|c|c|c|c|c|c|c|c|c|}
\hline \multicolumn{2}{|c|}{ DESCRIPTION } & \multicolumn{7}{|c|}{ Organizational Citizenship Behavior (Y) } \\
\hline Variable & Indicator & $\mathrm{Y}_{1}$ & $\mathrm{Y}_{2}$ & $\mathrm{Y}_{3}$ & $\mathrm{Y}_{4}$ & $\mathrm{Y}_{5}$ & $\mathrm{Y}_{6}$ & $\mathrm{Y}_{7}$ \\
\hline \multirow{3}{*}{$\begin{array}{l}\text { Organizational Climate } \\
\qquad\left(\mathrm{X}_{1}\right)\end{array}$} & $\mathrm{X}_{1.1}$ & 0,101 & 0,211 & 0,031 & $0,659 *$ & $0,615^{*}$ & $0,611 *$ & $0,654^{*}$ \\
\hline & $\mathrm{X}_{1.2}$ & 0,133 & $0,699 *$ & $0,692 *$ & 0,257 & 0,012 & 0,081 & 0,047 \\
\hline & $\mathrm{X}_{1.3}$ & 0,082 & 0,033 & 0,053 & 0,014 & 0,010 & 0,028 & 0,069 \\
\hline \multirow{5}{*}{$\begin{array}{l}\text { Personality } \\
\qquad\left(\mathrm{X}_{2}\right)\end{array}$} & $\mathrm{X}_{2.1}$ & 0,058 & 0,028 & 0,008 & 0,064 & 0,141 & 0,055 & 0,005 \\
\hline & $\mathrm{X}_{2.2}$ & $0,615^{*}$ & $0,643 *$ & $0,676^{*}$ & 0,106 & 0,189 & 0,084 & $0,743 *$ \\
\hline & $\mathrm{X}_{2.3}$ & 0,162 & 0,260 & 0,049 & $0,737 *$ & $0,622 *$ & $0,614^{*}$ & 0,281 \\
\hline & $\mathrm{X}_{2.4}$ & 0,243 & 0,016 & 0,166 & 0,321 & 0,148 & 0,009 & 0,118 \\
\hline & $\mathrm{X}_{2.5}$ & 0,212 & $0,608^{*}$ & $0,654 *$ & 0,015 & 0,130 & 0,291 & $0,711^{*}$ \\
\hline
\end{tabular}

Source: processed primary data (2019)

Notes:

1. Indicators of OCB: $\mathrm{Y}_{1}$ (Altruism), $\mathrm{Y}_{2}$ (Courtesy), $\mathrm{Y}_{3}$ (Carefulness), $\mathrm{Y}_{4}$ (Sportsmanship), $\mathrm{Y}_{5}$ (Civic Virtue), $\mathrm{Y}_{6}$ (Voice), $\mathrm{Y}_{7}$ (Boosterism)

2. Indicators of Organizational Climate: $X_{1,1}$ (Leadership Style), $X_{1,2}$ (Management Policies), $X_{13}$ (Recognition)

3. Indicators of Personality: $\mathrm{X}_{2.1}$ (Neuroticism), $\mathrm{X}_{2.2}$ (Extraversion), $\mathrm{X}_{2.3}$ (Openess to Experiences), $\mathrm{X}_{2.4}$ (Agreeableness), $\mathrm{X}_{2.5}$ (Conscientiousness).

4. Classification of Correlation Coefficient (Sugiyono, 2010): **Very Strong (0.80-0.99); *Strong (0.60-0.79); Moderate (0.40-0.59); Weak (0.20-0.39); Very Weak (0.01-0.19). 
Indicator Analysis Results above show that it had to be judged further which indicator should be recommended to be improved first and the next. This process utilized expertise judgment as a qualitative approach to make priority rank-order of those indicators. First priority to be recommended is to strengthen the leadership style effectiveness. By strengthening the effectiveness of leadership style it will open the effective way to improve management policies (the second indictor). Second priority to be recommended is to improve the process to formulate and decide the management policies which can be fairly accepted by all members of management. This process need the leadership style effectiveness. Third priority to be recommended is to improved personality variables namely extraversion, openness to experience and conscientiousness traits. Those traits could be improved by a specific training program from the psychologist. The improvement of leadership style and management policies will support the personality traits improvement.

\section{REFERENCES}

Adenike, A. (2011). Organizational Climate as a Predictor of Employee Job Satisfaction: Evidence from Covenant University. Business Intelligence Journal; 14, (1), 151-165.

Appelbaum, S., Bartolomucci, N. \& Beaumier, E. (2004). Organizational citizenship behavior: a case study of culture, leadership and trust. Management Decision; 42, (1), 33-41.

Arikunto, S. (2013). Prosedur Penelitian: Suatu Pendekatan Praktik. Jakarta: Rineka Cipta.

Asif, F. (1996). Estimating the impact of Denison's; (2011). What is the difference between organizational culture and organizational climate? A native's point of view on a decade of paradigm wars. Journal of Business Research; 64, (5), 454-459.

Bateman, T.S. \& Organ, D. W. (1983). Job satisfaction and the good soldier: the relationship between affect and employee citizenship. Academy of Management Journal; 26, 587-595.

Bolino, M.C. \& Turnley W.H., (2003). Going the extra mile: Cultivating and managing employee citizenship behavior. Academy oi Management Executive; 201D3. i7, (3), 60.

Burger, J.M. Personality. (2019). Boston, MA: Cengage Learning, Inc.

Chiang, C.F. \& Hsiesh, T.S. (2012). The impact of perceived organizational support and psychological empowerment on job performance: The mediating effects of organizational citizenship behavior.International Journal of Hospitality Management; 31, 180 190.

Colquitt, J.A., Lepine, J.A. \& Wessons, J.M. (2015). Organizational Behavior: Improving Performance and Commitment in the Workplace. New York: McGraw-Hill.

DiPaola, M.F., \& Tschannen-Moran, M. (2001). Organizational citizenship behavior in schools and its relationship to school climate. Journal of School Leadership; 11, 424-447.

DiPaola, M.F., Tarter, J. C. \& Hoy, W.K. (2004). Measuring Organizational Citizenship in Schools: The OCB Scale. Charlotte, NC; Information Age Publishing.

Ehrhart, M.G. \& Kuenzi, M. (2015). Organizational Climate in the Work Setting, in International Encyclopedia of the Social Behavioral Sciences, Second Edition ed., J. D. Wright, Ed., Oxford, Elsevier.

Fainshmidt, S. \& Frazier, M.L. (2017). What Facilitates Dynamic Capabilities? The Role of Organizational Climate for Trust. Long Range Planning; 50, (5), 550-566.

Feist, J., Feist, G.J. \& Roberts T.-A. 2018). Theories of Personality. New York: McGraw-Hill.

Fisher, R., McPhail, R. \& Menghetti, G. (2010). Linking employee attitudes and behaviors with business performance: a comparative analysis of hotels in Mexico and China. International Journal of Hospitality Management; 29, (3), 397-404.

George, J.M. \& Jones, G.R. (2012). Understanding and Managing Organizational Behavior. Upper Saddle River, NJ: Prentice Hall.

Gheisari, F., Sheikhy, A. \& Salajeghe, S. (2014). Explaining the relationship between organizational climate, organizational commitment, job involvement and organizational citizenship behavior among employees of Khuzestan Gas Company. International Journal of Applied Operational Research; 4, (4), 27-40.

Jorde-Bloom, P. (1988). Factors influencing overall job satisfaction and organizational commitment in early childhood work environments: $J$ Res Child Educ, 3 (2), 107-122 
Katz, D. \& Kahn, R. L. (1966). The social psychology of organizations, New York, NY: Wiley.

Khaeruddin. (2020). Effects of Organizational Climate on Organizational Citizenship Behavior. Journal of Education, Humaniora and Social Sciences (JEHSS); 2, (3), 554 - 553

Kholisah, I.N., Sampeadi. \& Apriono, M. (2020). The Effect of Organizational Culture and Personality on Organizational Citizenship Behavior mediated by Organizational Commitment on the Employees of PT Bank Tabungan Negara (Persero) Tbk Jember. e-Journal Ekonomi Bisnis dan Akuntans; VII, (1), 72-76.

Langton, N., Robbins, S.P. Judge, T.A. (2016). Organizational Behavior: Concept, Controversies and Applications. Ontario: Pearson Canada, Ltd.

Messersmith, J.G., Patel, M.P., \& Lepak, D.P., 2011. Unlocking the black box: exploring the link between High-Performance Work Systems and performance. J. Appl. Psychol. 96, 11051118.

Moorman, R.H.,Niehoff,B.P., \& Organ,D.W.(1993). Treating employees fairly and organizational citizenship behavior: Sorting the effects of job satisfaction, organizational commitment, and procedural justice. Employee Responsibilities and Rights Journal; 6, 209-225.

Mushraf, A. M., Al-Saqry, R., \& Obaid, H. J. (2015). The Impact of Big Five Personality Factors on Organizational Citizenship Behavior; International Journal of Management Science, 2, (5), 93-97

Nolan, S.A. and T.E. Heinzen. (2012). Statistics for the Behavioral Sciences. New York: Worth Publisher.

O.P. John, S. Srivastava, et al. (1999). The big five trait taxonomy: History, measurement, and theoretical perspectives, in: Handbook of Personality: Theory and Research, 2, 102138.

Oguz, E. (2010). The relationship between the leadership styles of the school administrators and the organizational citizenship behaviours of teachers. Procedia Social and Behavioral Science; vol 9, 1188-1193.

Organ, D. W. (1997). Organizational citizenship behavior: It's construct clean-up time. Human Performance Journal; 10, 85-97.
Oyesiku, K. \& Omitogun, O. (1999). Statistics for social and management sciences. Lagos Higher Education Books Publisher.

Peltonena,E., Sharmila, P., Asarea, K.,O., Visuria, A., Lagerspetz,E.\& Ferreira,D.(2020). Whenphones get personal: Predicting Big Five personality traits from application usage. Pervasive and Mobile Computing Journal, vol 69, 101269. https://doi. org/10.1016/j.pmcj.2020.101269

Podsakoff, P.M., Ahearne, M. \& MacKenzie, S.B. (1997) Organizational citizenship behavior and the quantity and quality of work group performance. Journal of Applied Psychology; 262-270.

Popescu, A.M., Deaconu, A.. \& Popescu, T., (2014) The impact of gender difference at Romanian small and medium enterprises (SME) management level, analyzed by organizational citizenship behavior (OCB) lens. Procedia Economics and Finance; 8, 563 - 569

Pourkiani, M, Farokhian, A. \& Gheisari, F. (2014). Explaining the Relationship Between Organizational Climate, Organizational Commitment and Organizational Citizenship Behavior Among Employees of Khuzestan Gas Company. Indian Journal of Fundamental and Applied Life Sciences; 4 (S3), 282-290.

Robbins, S.P. \& T.A. Judge. Essentials of Organizational Behavior. (2013). New York: McGraw- Hill.

Schneider, B. \& K.M. Barbera. (2014). The Oxford Handbook of Organizational Climate and Culture. Oxford, UK: Oxford University Press.

Sekaran, U. \& R. Bougie. 2013. Research Methods for Business. West Sussex, UK: John Wily \& Sons.

Singh, A.K., \& Singh, A.P. (2009). Does personality predict organizational citizenship behavior among managerial personnel. Journal of the Indian Academy of Applied Psychology; 35, (2), 291-298.

Sugiyono. (2010). Metode Penelitian Pendidikan: Pendekatan Kuantitatif, Kualitatif, dan R\&D. Bandung: Alfabeta.

Sukanti, L., Hardhienata, S. \& Retnowati, R. (2017). Relationship Between Organizational Culture, Motivation, and Personality to Organizational Citizenship Behavior. International Journal of Innovative Research in Science, Engineering and Technology, 6, (10), 20246-20249. 
Supardi U.S. (2012). Aplikasi Statistika dalam Penelitian. Jakarta: UFUK Press.

Turnipseed, D.L. (2005). Handbook of Organizational Citizenship Behavior. New York: Nova Science Publisher, Inc.

Uhl-Bien, M., Schermerhorn, J. R., Jr., \& Osborn, R. N. (2014). Organizational Behavior. Hoboken, NJ: John Wiley \& Sons.
Zeinabadi, H. (2010). Job satisfaction and organizational commitment as antecedents of Organizational Citizenship Behavior (OCB) of teachers. Procedia Social and Behavioral Science; (5), 998-1003. 